\title{
Intermédialités
}

Histoire et théorie des arts, des lettres et des techniques

Intermediality

History and Theory of the Arts, Literature and Technologies

\section{Doors and Perception: Fiction vs. Simulation in Games}

\section{Espen Aarseth}

Numéro 9, printemps 2007

Jouer

Playing

URI : https://id.erudit.org/iderudit/1005528ar

DOI : https://doi.org/10.7202/1005528ar

Aller au sommaire du numéro

Éditeur(s)

Centre de recherche sur l'intermédialité

ISSN

1705-8546 (imprimé)

1920-3136 (numérique)

Découvrir la revue

Citer cet article

Aarseth, E. (2007). Doors and Perception: Fiction vs. Simulation in Games. Intermédialités / Intermediality, (9), 35-44. https://doi.org/10.7202/1005528ar
Résumé de l'article

Dans cet article, l'auteur esquisse une théorie du rapport entre les éléments fictifs, virtuels et vrais dans les jeux vidéo. Peu d'attention critique a été accordée au concept de fiction lorsque celui-ci est appliqué aux jeux vidéo ainsi qu'aux mondes vidéoludiques et ce, en dépit des nombreux ouvrages et articles qui utilisent le terme, souvent même dans leur titre. Il s'agit de montrer que ces mondes vidéoludiques et leurs objets sont ontologiquement différents des mondes fictifs; ils sont empiriquement soutenus par le moteur du jeu, et non par notre esprit stimulé par de l'information verbale. De plus, des phénomènes vidéoludiques tels que les labyrinthes confirment que les jeux peuvent contenir des éléments qui sont aussi vrais que leurs équivalents à l'extérieur du jeu, bien que fort différents de leurs homologues fictifs. 


\title{
Doors and Perception: Fiction vs. Simulation in Games
}

\author{
Espen Aarseth
}

\section{INTRODUCTION}

In discussions of mimetic games, that is, games that represent events, beings and worlds in a way that makes it possible for these elements to be recognized independently of the game, it is not uncommon to talk of these as part of the game's "fiction." This may seem reasonable at first sight, for the phenomena in question are not-or do not seem-real, the way phenomena in our real world are or seem real; hence they must be imaginary, illusory, fabricated: fictional. An invented character in a novel or a movie is fictional, so why should it not follow that an invented character in a game also is fictional? Critical questions about the status of fiction in games are rarely asked, and the concept of fiction is not interrogated before it is put to use in game studies. Even in quite sophisticated discussions, such as Rune Klevjer's "In Defence of Cut Scenes," Nick Montfort's Twisty Little Passages: An Approach to Interactive Fiction ${ }^{2}$ or Jesper Juul's HalfReal: Video Games Between Real Rules and Fictional Worlds ${ }^{3}$, the term fiction is used without qualification, nor seen in need of redefinition or reassessment. From the earliest writings on computer games, such as Holland and Niesz' "Interactive Fiction"4 from 1984, the term fiction has been taken for granted.

1. Rune Klevjer, "In Defense of Cut Scenes," in Frans Mäyrä (ed.), Computer Games and Digital Cultures Conference Proceedings, Tampere, Tampere University Press, 2002, available online at http://www.uib.no/people/smkrk/docs/klevjerpaper.htm.

2. Nick Montfort, Twisty Little Passages: An Approach to Interactive Fiction, Cambridge, The MIT Press, 2003.

3. Jesper Juul, Half-Real: Video Games between Real Rules and Fictional Worlds, Cambridge, MIT Press, 2005.

4. Anthony J. Niesz, Norman N. Holland, "Interactive Fiction," Critical Inquiry, Vol. 11, No. 1, 1984, p. 110-129. 
However, as I will demonstrate in this paper, 5 the category of fiction is problematic when applied to "game content." Here, the idea that game content is fictive will not be taken for granted, but will be critically examined. I do not engage fiction theories from literature such as Pavel $^{6}$ or Walton ${ }^{7}$, but base my use of the term on its simple dictionary meaning. Fictions do not have to be logical or consistent, as long as they make us project mental images, happenings and notions. Nor are (literary) fictions the same as "games of make-believe," ${ }^{8}$ since they rely on words and texts independent of the reader, unlike children playing games of pure make-believe, where the player is in control, and can change the world and its conditions at will.

As for the concept of the real, I simply adopt Phillip K. Dick's expert definition: "Reality is that which, when you stop believing in it, doesn't go away."9

The gist of the argument is simply this: computer software is a kind of metamedium that is able to emulate the older media of text, image, and film. Hence, a computer game is able to contain and present fictional elements without effort. This can be observed especially well in phenomena such as machinima, or in a game's cut scenes, where a game engine is used to produce animated movies. In short, games may well contain fictional content. But they also contain content that is different from the elements we recognize from older media. These elements are ontologically different, and they can typically be acted upon in ways that fictional content is not acted upon. This does not mean that they are necessarily real, merely that they belong to another ontological category than, say Tintin's dog or the pyramid floating over Paris in Hergé's and Bilal's comic books, respectively. We respond to them differently, they are constructed differently, and the social exchanges they are part of are different from the social uses of fiction. So what are they?

5. I originally made this argument in a 1994 article, "Nonlinearity and Literary Theory," in George P. Landow (ed.), Hyper/Text/Theory, Baltimore, Johns Hopkins University Press, 1994, p. 51-86, reprinted in Noah Wardirp-Fruin, Nick Montfort (eds.), The New Media Reader, Cambridge, Massachusetts, The MIT Press, p. 762-780, and later in my book on games and literature, Cybertext: Perspectives on Ergodic Literature, Baltimore, London, Johns Hopkins University Press, 1997.

6. Thomas G. Pavel, Fictional Worlds, Cambridge, Harvard University Press, 1986.

7. Kendall Walton, Mimesis as Make Believe: On the Foundations of the Representational Arts, Cambridge, Harvard University Press, 1990.

8. Kendall Walton, Mimesis as Make-Believe.

9. Philip K. Dick, "How to build a universe that doesn't fall apart two days later," in I Hope I shall Arrive Soon, New York, St. Martin’s Press, 1985, p. 1-26. 


\section{DRAGONS VS. DRAGONS}

Consider a dragon. These beasts do not exist in our world, but are part of imaginary worlds in literature, film, and games. However, the literary, fictional dragon, say Tolkien's Smaug, is different from the simulated dragons we find in a game such as EverQuest (Verant Interactive, 1999).

They are not the same, or there would have been no difference between our experience of Tolkien's world and the world of EverQuest. One dragon is clearly fictional, but the other is simulated. ${ }^{10}$ One is there to read about, or watch on a TV or movie screen, the other is there to be played with. One is made solely of signs, the other of signs and a dynamic model, that will specify its behaviour and respond to our input. It is this model behaviour that makes it different from a fiction since we can get to know the simulation much more intimately that we come to know the fiction. A fiction is rarely, if ever, personal, while a simulation can become so through experience. Simulations allow us to test their limits, comprehend causalities, establish strategies, and effect changes, in ways clearly denied us by fictions, but quite like in reality. We can't have our way with fictions, but with games, we may.

Of course, it can be argued that the fictionality of Tolkien's dragon lies in the fact that it simply has no counterpart in reality, and not in the material way it happens to be presented to us in games or stories. In other words, the argument would go, both dragons are equally fictitious, they just happen to be presented in different media. A picture of a relative, say, uncle Oswald, is not a fiction, but a materially similar still from a movie, say Captain Blood (Michael Curtiz, 1935), is. Our uncle Oswald is real, the character portrayed by Erroll Flynn is fictional. However, what to make of a simulation of uncle Oswald? Would it be real or documentary, like his photograph, or fictive like the picture of Captain Blood? And what would be the difference between a simulation of Captain Blood, and a simulation of uncle Oswald? The claim that there is any difference in fictiveness between the two simulations would be hard to maintain.

These are of course hypothetical examples, but consider instead two first person shooter games, Call of Duty (Infinity Ward, 2003), and Brothers in Arms: Road to Hill 30 (Gearbox, 2005). Both are set in WW II, but the former is based on action sequences from movies like Enemy at the Gates (Jean-Jacques Annaud, 2001), and the latter is based on historically accurate action accounts and faithfully modelled on historical post-D-day battles and environments (Carentan,

10. Jesper Juul, also using the example of a game dragon, claims that the game dragon is fictional, and not real, but such a claim clearly ignores the third possibility, that it is virtual, simulated. See Jesper Juul Half-Real: Video Games between Real Rules and Fictional Worlds. 
Sainte-Mère-Église, etc.), down to accurate architectural details on the real farm houses in the French countryside, which the development team visited and charted. Are the events and existents of Call of Duty fictional and those of Road to Hill 30 real? In the case of a documentary vs. a fiction film or text, this question would have been easy to answer in the positive. The two games, however, are ontologically similar, and practically identical for the purpose of this discussion. To classify one as fictional and the other as documentary would make little sense. A virtual bullet fired in one game is neither more documentary nor more fictional that a bullet in the other."

Both games direct their users within a very narrow quest corridor, with almost ridiculously unnatural boundaries for the player-character's movements (e.g., three feet tall fences that are impossible to cross). Nonetheless, there are important differences between the two games: Call of Duty's landscapes and missions are more pompous and "heroic" or romantic, while Road to Hill 30 is more monotonous, both in the range of tasks and in the types of landscapes.

\section{THE MEANING OF FICTION}

Before we continue, I will briefly clarify the concept of fiction as it is used here. Etymologically, the word stems from the Latin fingere, to shape or form. Given this originally broad meaning, it might seem reasonable to use fiction also for virtual objects, unless one considers that then it would be reasonable to include all other human-made things, such as cars, houses or velcro. These are not fiction, and to expand the term to include them is hardly wise. A standard dictionary (in this case, Encarta) lists two meanings of fiction:

1. novels and stories that describe imaginary people and events; and

2. something that is untrue and has been made up to deceive people.

In other words, fiction normally means two different things: either fairy tales, or lies. Here, of course, we use meaning 1: invented phenomena. A (literary) fiction is not a lie: it has no truth value in our world. For instance, take Pinocchio's nose: is it true or false that it grows? The question, in our world, is meaningless. However, in a hypothetical game, where we could influence the length of a simulated nose, and perhaps win or lose depending on how long it is, its growth would be as real to us as that of a flower in our garden.

11. Of course, the distinction between fiction and documentary is also problematic in itself, since a movie filmed in a real city is in a sense also partly a documentary of that city at a specific moment, and most, if not all, fictions contain some reference to our reality. 
When we play games, in real or virtual environments, we really win or lose, and the events in the games are real, even if, for a casual observer, they might be indistinguishable from a similar sequence in, say, an animated fiction film. The bullets in a game of Counter-Strike (Valve, 2000) are not real bullets, but neither are they fictional. The virtual bullets in JFK Reloaded (Traffic Management, 2004), while simulating the bullets that killed the real JFK, are not ontologically different from any other virtual bullets with the same properties. Are they documentary bullets? Yes, but no more so than the other virtual bullets, and the bullets of Call of Duty and Road to Hill 30.

In short, games are not fictions, but a different type of world, between fiction and our world: the virtual. There are also other worlds: dream worlds, thought experiments, religious perceptions, mirror worlds, etc. All these are different alternatives to our own world, and as different from fiction as they are from each other.

\section{LABYRINTHS AND MAZES}

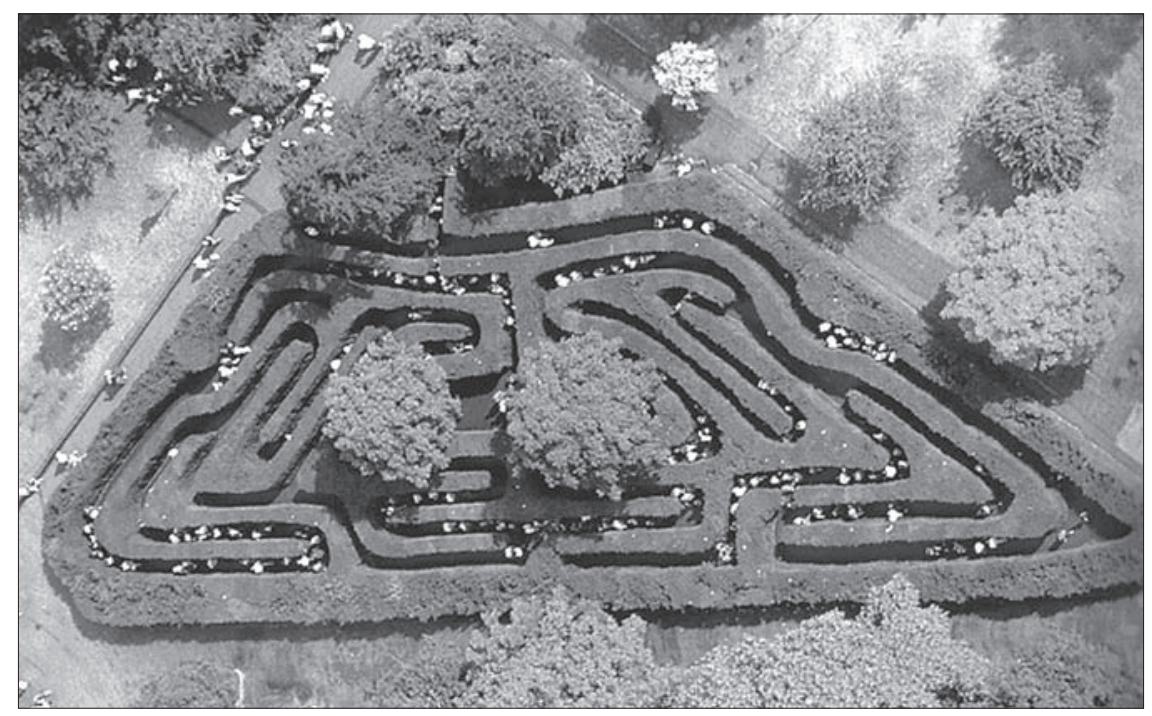

Fig. 1. The real maze at Hampton Court.

A labyrinth is a very common structure in many types of games. It is also a perfect illustration of the difference between a game object and a fictional object. Labyrinths exist in the real world, in fictions, and in games, from Pac-Man (Namco, 1979) to The Chronicles of Riddick: Escape from Butcher Bay (Vivendi Games, 2007). A very famous real-world labyrinth would be the hedge maze at Hampton 
Court, England. (Fig. 1) A similar but fictive labyrinth is the one we find in Kubrick's movie The Shining (1980), outside the spooky Overlook Hotel. Kubrick's labyrinth looks real, but as we shall see, is completely fictional. The Pac-Man labyrinth, however, does not look like a real-world labyrinth, unless we consider that labyrinths do not have to be made of wood, stone or a planted hedge. Labyrinths, made by humans since before recorded history, are also painted designs that could be on a wall, a page, a floor or a computer screen. Some are kneedeep, some are 10 feet tall, some are outdoor, some are indoor, and some are found at the backs of comic books or in weekly magazines.

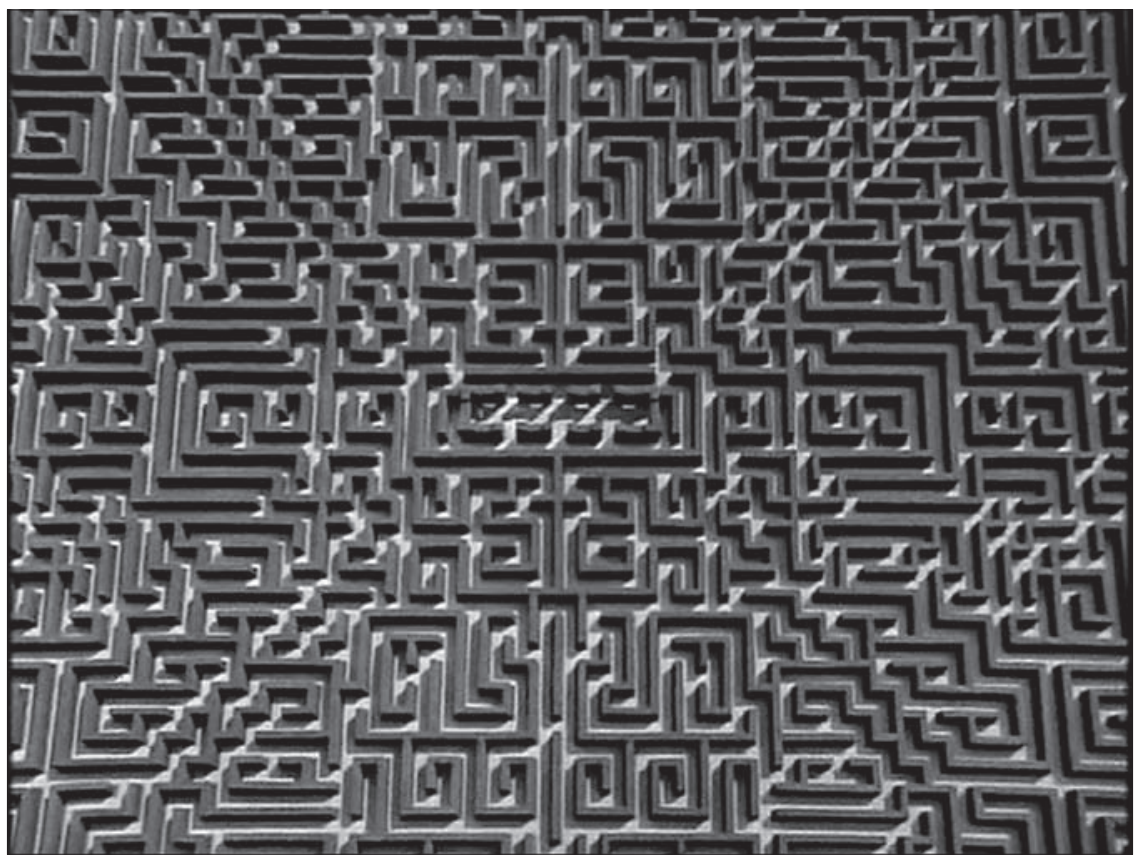

Fig. 2. A bird's-eye perspective on The Shining's fictional maze.

If we examine Kubrick's labyrinth closely, however, we discover that it does not really exist at all, but is an illusion, a chimera, designed to support the fictive events. The Shining's fictional labyrinth is presented in several ways. We see close-ups of the main characters exploring it, we see it as a model inside the hotel, and there is a bird's-eye shot (Fig. 2) showing two people walking in its middle. Comparing these different views, however, reveals that we are not looking at the same labyrinth, but at slightly different ones. Also, the real-world hotel where the film was shot, the Timberline Lodge in Oregon, does not have an actual garden maze like the film suggests. 


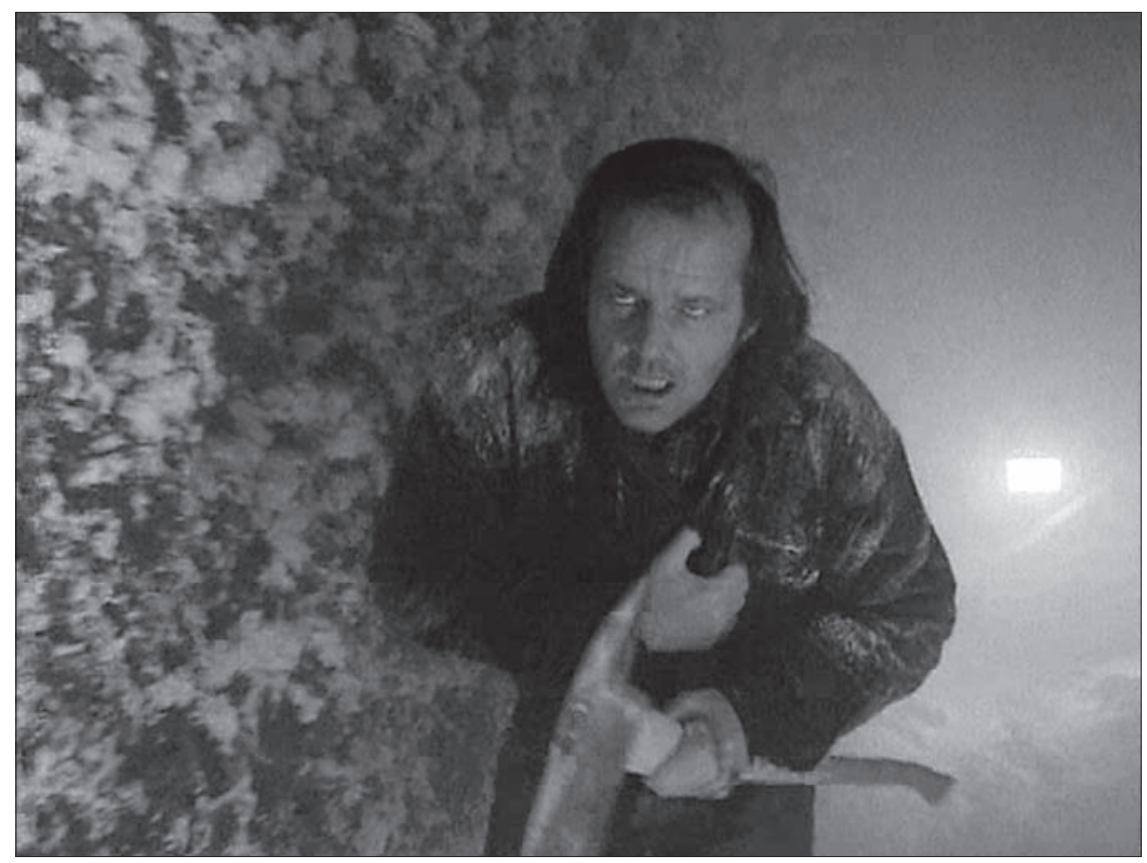

Fig. 3. Real actor, fake maze: Jack Nicholson in The Shining (Stanley Kubrick, 1980).

In the "Making of..." documentary that accompanies the film on the DVD (Making The Shining, Vivian Kubrick, 1980), there is a very revealing scene where Kubrick walks from his film studio office through a backstage area and directly into the scene where the boy is chased by his father through the snowy maze. (Fig. 3) In one scene of the documentary there is also a glimpse of the blueprint of the film-set maze, which is clearly different from the model in the hotel, and also different from the vertical shot of the maze from above. Kubrick creates the illusion of a maze by creating at least three different filmed objects that together give life to a fictional object. If the film had been shot at Hampton Court, the claim could have been made that the maze was real even if the film as such was a fiction, but in The Shining we see a clear example of a maze that does not exist. It is completely fictional, e.g. unlike, say, the labyrinths of games, which are real labyrinths. For what constitutes labyrinthicity? If a $2 \mathrm{D}$ drawing or a painted or tiled floor can be a proper labyrinth (and they can, since labyrinths do not come with specific height requirements) then a $3 \mathrm{D}$ virtual labyrinth in a computer-simulated world is a real labyrinth, since it can be navigated by the same rules as the one at Hampton Court. (Incidentally, I was quite disappointed by my experience of the Hampton Court labyrinth, because it took only seven minutes to walk through it, using the well-known wall-hugging technique.) 


\section{DOORS AND PERCEPTION}

However, some objects in games are clearly fictional, just as they would be in movies. Take for instance a game like Return to Castle Wolfenstein (Gray Matter, 2001), a 3D shooter where a typical setting would be a German town or village during WW II. The player-character walks through the streets and alleys, looking for clues to the right direction, while keeping an eye out for German troops. He sometimes has to enter houses, but here is the strange thing: only some of the doors in the game actually work as doors should. Most of the doors are merely textures on the walls that look like doors, but whose function is purely decorative. Other doors actually do behave in a door-like manner; they can be opened, closed, seen through, walked through and fired through.

Clearly, these two types of door are very different, and the first type is obviously fictional; it behaves like an unused door in a film, or a closed door in a painting. The game is not making a statement to the effect of "in Wartime Germany, most doors were fake, simply painted on." So if the first type of door is fictional, what is the second type? Is it also fictional? If we conclude this, then we are clearly looking at two very different types of fiction, with only the first type being similar to fictional phenomena in all other media. For the sake of well-conceived theory, it makes more sense to conclude that there are both fictional and non-fictional doors in these games, and that the non-fictional doors are virtual, a mode of existence that is neither fictional nor real. These doors are simulated, like a game dragon but, importantly, unlike a game labyrinth, which is both virtual and real: virtual in a physical sense, but real in a conceptual sense. The virtual doors and dragons, however, are neither physically nor conceptually real, but merely simulated. So what should we call them? Virtual or simulated, both terms will probably do.

It follows that there are at least three different ontological layers to game content: the real, the virtual and the fictional. In the early text adventure games, the fictive layer often dominated, with fixed descriptions that changed very little or not at all. With today's increasingly more physics-heavy $3 \mathrm{D}$ games, the drive away from fiction towards simulation continues with the development of dedicated physics processors (PPUs), in order to emulate real-world physics ever more faithfully. This movement parallels the rapidly rising cost of game development: fiction is cheap; simulation is expensive. Take Half-Life 2 (Valve, 2006), a game that is at its most impressive in terms of its highly believable environments and physics: the highly narrow and one-dimensional quest corridor may be a testament to the storytelling ambitions of the game designers, but it is also a practical consequence of the high production cost of game landscapes. Open up the landscape and the budget grows exponentially. In other words, freedom of 
movement and quality of world-representation are inversely proportional, given a fixed development budget. For every virtual door, an additional room must be created behind it; for every fork in the road, more graphics artists must be hired. Perhaps the most brilliant aspect of HL2's design is the way every landscape contains a single "natural" direction, too subtle to be truly annoying, and with "natural" boundaries that seem to make sense in the constrained atmosphere of the game. The fictive and the virtual aspects are balanced by designers who are experts in the making of natural-feeling boundaries. Towards the end of HL2, when the player-character is transported through the gigantic innards of the alien tower, the vast, multidirectional openness of the setting is matched by the fact that Gordon Freeman is locked into a metal straightjacket, moving on a rail.

\section{Virtual capital, REAL estate}

If Half-Life 2 is a good example of a balance between fictional and virtual elements, then massive multiplayer online games (MMOGs) such as EverQuest provide good examples of a balance between real and virtual elements, especially in the case of money. As is well known, game objects and player characters and, not least, in-game currencies can be bought and sold on web-sites like Ebay and Playerauctions.com, and this effectively means that EverQuest money, the Platinum or Plat, is a real currency, just like the Brazilian Real, the Korean Won, or the European Euro. The value of every currency in the world is relative to other currencies, and there is no absolute value that can be maintained independent of a currency's exchange value. This makes MMOG money just another currency, as real or virtual as my monthly paycheck. So when I play a game like EverQuest, the money in my virtual pocket is as real as the virtual money in my real bank account outside the game. I have worked for both, I spend both to make my life more comfortable, and I can exchange one for the other. Should I choose to, like Julian Dibbell ${ }^{12}$ recently did, I can decide to go to work in the MMOG and let that be my main source of income. And while there, I can do business with other players, earn their respect, and perhaps even fall in love. Some MMOGs allow the purchase of in-game virtual real estate. I can invest in land, and own parts of a virtual world. To describe this pursuit of the most important of life's values, the concept of fiction would not apply very well, if at all. A MMOG may be a place of deceit and illusion, but in a real sense, not in a fictional one. There are

12. Julian Dibbell, Play Money: Or, How I Quit My Day Job and Made Millions Trading Virtual Loot, New York, Basic Books, 2006. 
no fictional dragons in EverQuest, and very few, if any, fictional doors. Lies, yes, but real lies. If Half-Life 2 balances between fiction and virtual, then MMOGs balance between the virtual and the real.

Money is of course found in many types of games besides MMOGs and persistent world games. In RPG, action, and adventure games like Diablo (Blizzard Entertainment, 2003), Counter-Strike or Resident Evil 4 (Capcom, 2005), money is collected and is used to buy better equipment, thus clearly having a real and important impact on the rest of the gameplay. In these games, however, the money is not real in the sense of MMOGs; there is no real-world exchange rate or trade between players. So in this case, as with Monopoly, the money is virtual, in the sense that its effects are limited to the in-game situation. There is also fictional money in some games, that is, money that has a purely decorative

44 function, and cannot be used at the player's discretion to influence the game state. The reality of money is a function of the social character of the games, just as it is with interplayer relationships in general.

\section{CONCLUSION}

In this paper I have tried to build a game-oriented theory of fiction, simulation and reality from a bottom-up perspective, as empirical phenomena in games, and not paid any particular attention to theories dealing with fiction in literature or film. While it seems obvious that many games do contain fictional elements that support the game's purpose, it is also clear that these elements are not as important and dominant as fictional elements in, well, fiction, and that they enter into complex relationships with the other ontological elements of games, both the virtual and the real. Despite the complex nature of these relationships, however, my analyses show that it is quite possible to distinguish between fictional, virtual and real instances of the same nominal phenomenon. This means that instead of the common notion that game worlds are fictional, we should start to see them as composites where the fictional elements is but one of the many types of worldbuilding ingredients.

As the labyrinth example indicates, many game objects are conglomerate, consisting of virtual, real and fictional elements. A game labyrinth is a real topological object, consisting of virtual walls, whose material nature (e.g. wood) may be entirely fictional. 